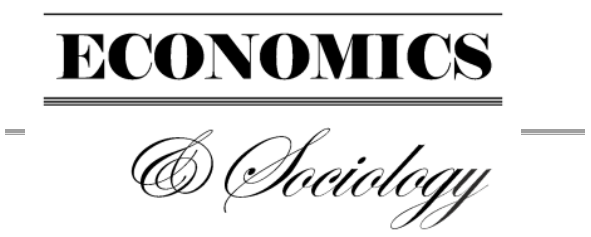

Aliekperova, N. (2018). Pharmaceutical leadership in Ukraine: Transformational and transactional. Economics and Sociology, 11(4), 265-279. doi:10.14254/2071789X.2018/11-4/17

\title{
PHARMACEUTICAL LEADERSHIP IN UKRAINE: TRANSFORMATIONAL AND TRANSACTIONAL
}

\author{
Nataliia Aliekperova, \\ Bogomolets National Medical \\ University \\ Kiev, Ukraine, \\ E-mail: \\ aliekperova18@gmail.com
}

Received: August, 2018

1st Revision: September, 2018

Accepted: November, 2018

DOI: $10.14254 / 2071-$

789X.2018/11-4/17
JEL Classification: D23, M19, M54.

\begin{abstract}
The article is devoted to the analysis of B. Bass's transformational and transactional leadership factors on the example of pharmacies and pharmaceutical organizations of Ukraine. Based on the survey results through the Multifactor Leadership Questionnaire (MLQ) for managers and employees of the organizations mentioned, the application peculiarities of transformational, transactional and laissez-faire leadership in managing Ukrainian pharmacies and pharmaceutical organizations are researched. It was found out that the managers appreciated more their leadership qualities: the highest score related to the transactional leadership factor of a contingent reward, while the employees noted that their managers most often used such a transactional leadership factor as the management-by-exception (active). Research and practical recommendations as to the application of transformational, transactional and laissez-faire leadership principles in Ukrainian pharmaceutical organizations are proposed.
\end{abstract}

Keywords: transformational and transactional leadership, pharmacies, pharmaceutical organizations, Ukraine.

\section{Introduction}

Organizational management and development greatly depend on its leaders' behaviour, their system of values, vision, and attitude to employees. It is the leader who is the organization's driving force, as he/she determines its vision, creates the team, lays the foundations for its corporate culture, determines its general development strategy, which is reflected in earlier leadership theories (the great man theory, the trait approach), as well as in later ones (transformational leadership, adaptive leadership). Notwithstanding the fact that leadership is the key development factor of any organization, irrespective of its activity field as it has been proved by researches conducted in large international organizations (Zwingmann et al., 2014). Pharmaceutical branch, however, has its specific features, in particular, higher level of innovations to satisfy the growing people's needs in preserving and supporting their health. Thus, on average, the biggest global pharmaceutical companies spend about $20 \%$ of their annual turnover on $\mathrm{R} \& \mathrm{D}$, and their success is determined by the 
development and introduction of new original drug and healthcare products (Evaluate Pharma World Preview, 2017). According to the transformational and adaptive leadership theories, high level of innovations in a company and change management is impossible without effective leadership, which is the token of continuous development, search, and implementation of new effective decisions for complicated organizational challenges. However, apart from pharmaceutical industry, the wholesale pharmaceutical companies and pharmacies highly need effective leadership as well. These companies face such challenges as adaptation to tough competition from the side of both traditional and e-commerce companies, organization of new forms of entrepreneurial activity, and also the need for functional processes' automation. At the same time, it is necessary to provide consumers with effective and safe drugs and healthcare products and relevant pharmaceutical care overall which certainly requires careful holistic leadership approach.

It should be noted that it is not just about the leader's traits and aspirations that determine his/her effectiveness, but also cooperation with the followers as well, leading to a desirable for the leader result. Fruitfulness of this cooperation depends not only on the leader's ability to set ambitious and practicable goals but also on his/her capability to motivate and inspire employees, as described in B. Bass's theory of transformational leadership (1990). According to this theory, two main leadership styles are given attention: transactional leadership, which implies a mutually beneficial exchange between a manager and employees, and transformational leadership, which means employees' development and inspiration for achieving a desired result.

The object of this research is the leadership factors in the context of B. Bass's transformational and transactional leadership theory.

The purpose of the research is the analysis of transformational, transactional and laissez-faire leadership application in pharmacies and pharmaceutical organizations of Ukraine. To achieve this purpose, the following research tasks have been set forward:

- to conduct literature review on transformational, transactional, and laissez-faire leadership, also including companies of the pharmaceutical sector;

- to analyse the application specifics of transformational, transactional and laissezfaire leadership within pharmacies and pharmaceutical organizations of Ukraine;

- to propose practical recommendations as to the application of transformational, transactional and laissez-faire leadership principles in the work of managers of Ukrainian pharmacies and pharmaceutical organizations.

\section{Literature review}

James Burns (1978) described a transformational leader as a person who can conduct radical changes: "...cause a metamorphosis in form or structure, in change in the very condition or nature of a thing..." to achieve a result which is radically different from what, for instance, a transactional leader does. Burns characterized a transactional leader as a broker whose role is "relatively minor, even automatic", and does not presuppose decision taking beyond the accepted norms. Burns points out that a "vigorous interaction between transforming leaders and their followers is itself a powerful causal force for change", defining the role of a transformational leader as of a progressive person, mobilizing the followers in the process of implementing changes, inspiring them to feats and giving people a sense of their own value and importance, forming the idea of collective identity and effectiveness. He emphasizes that "instead of exercising power over people, transforming leaders champion and inspire followers". At the same time James Burns draws attention to differentiation between a transformational leader, a dictator and a purely charismatic leader: "at best, charisma is confusing and undemocratic form of leadership. At worst, it is a type of tyranny". Besides, he 
suggests certain criteria which, in his view, differentiate a transformational leader from a dictator, and specifically "such lofty public principles as order, liberty, equality, justice, the pursuit of happiness".

In the 1980-ies Bernard Bass (1985) complemented and enlarged Burns' transformational theory, focusing on business-leadership; besides, he took into account the charismatic leadership theory by House (1976), in which the latter links the charismatic leader's personal traits and behaviour with his ability to influence the followers. Bernard Bass accentuated rather the followers' needs than those of a leader, the necessity to raise people's awareness of the importance and significance of the goals, of their orientation not only on personal, but also on corporate interests, as well as on forming the followers' high level needs, their desire for creativity and innovations.

The author points out the following factors of transformational leadership:

- idealized influence, which implies a leader's statement of clear vision of the organization development, of understandable and important for the employees values, moral and ethical standards, the creation of the climate of mutual trust and readiness to meet organizational changes;

- inspiring motivation is motivating people for achieving the goals, empowering them with confidence and enthusiasm, explaining them the importance and realization necessity of the planned/intended initiatives;

- intellectual stimulation, which means stimulation of the followers' intellectual potential, the search of innovative ways for goal achievement, support of individual initiatives, openness in accepting and analysing of new ideas;

- individualized consideration, which means teaching and developing people, care for the followers' values, expectations, abilities and aspirations; help in determining and developing the employees' strengths, focusing on the necessity of their selfdevelopment.

B. Bass considered transactional leadership as a meaningful and necessary element in business-leadership, which, nevertheless, has certain limits, as it does not imply a superior leadership position - an exceptionally mutually beneficial exchange between a leader and employees, which is a "prescription to mediocrity". He points out the following transactional leadership factors:

- contingent reward presupposes the exchange between a leader and his followers, where the effect from employees' activity is exchanged for granting them a certain reward. In this case, individual goals of the leader and the follower are accentuated; for instance, a pharmacist is offered either an additional monetary compensation or a promotion for agreeing to work in a geographically remote pharmacy;

- management-by-exception $(M B E)$ is considered from the point of view of two factors: active and passive. Active "situation management" means the administration errors and gaps of employees in the performance of their tasks and the correction of their actions to achieve the desired result. Passive "situation management" is characterized by non-interference of the manager in the process of task execution, he reacts only to the consequences of errors and current problems;

- such factor as laissez-faire leadership was pointed out; it implies the leadership absence, when a leader avoids responsibility, postpones decision making, provides no feedback and does not care in the least about the satisfaction of his employees' needs.

Bass and Avolio (1994) showed up that a contingent reward is an effective instrument for achieving organizational goals, as it encompasses clear and understandable goal setting and the expected remuneration, while MBE-active leadership had no tangible influence on the employees' effectiveness; and such styles as management by exception-passive and laissez- 
faire leadership were ineffective. Avolio (1999) noted that laissez-faire leadership is "poor, ineffective leadership and highly dissatisfying for followers".

In Bass's view, transformational leadership amplifies the effects of transactional leadership: "performance beyond expectation", which leads to an increase in the efficiency of staff, and subsequently, to improve financial performance. The augmentation effect of transformational leadership is confirmed by a number of researches, for instance, by Rowold and Heinitz (2007), who also noted that transformational and charismatic leadership are somewhat alike, but they differ from transactional leadership; Nemanich and Keller (2007) determined on the example of a big multinational company, in the process of merging and formation of a new organization, that the transformational leadership factors (idealized influence, inspiring motivation, intellectual stimulation, individualized consideration) provide a positive influence on employees' anticipation of organizational changes, on their work satisfaction and effectiveness. Paulsen et al (2013), having conducted the research in a large Australian R\&D organization, confirmed their hypotheses as to the transformational leadership positive influence on the team climate in organizations engaged in research and also on the innovativeness of these organizations. The use of transformational leadership facilitates the development and maintenance of innovative corporate culture. Besides, the authors paid attention to the fact that this leadership style was favourable in organizational changes, as employees' support and inspiration facilitate their resistance reduction as to the initiated changes and the achievement of desired corporate goals. A number of researches (Xenikou, 2017; Sagnak et al, 2015; Gryazeva-Dobshinskaya et al, 2014; Rabia et al, 2009, Jung Dong et al, 2003) also confirmed the positive correlation between the transformational leadership and the innovative corporate climate in the organization. Zwingmann et al (2014), conducting the research in 16 countries, substantiated the transformational leadership positive influence on the health and well-being of organizations' employees.

The validity and reliability of transformational leadership theory was proved in the meta-analysis of 39 studies on leadership (Lowe et al, 1996); besides, it was noted in this research that people who demonstrate the transformational leadership behaviour are anticipated as more effective leaders with a better organizational result than those who apply only the transactional leadership principles. The meta-analysis results of 87 sources (Judge \& Piccolo, 2004) also showed a great validity not only of transformational, but also of transactional and laissez-faire leadership.

The transformational leadership theory had its continuation; thus, Warren Bennis and Burt Nanus (1985), based on a survey of 90 leaders, determined four leadership strategies for the successful organization transformation:

- representation of clear, convincing and attractive vision of the organization's future development;

- creation of social "architecture" determining the organizations' system of values, which is understandable and close to people and facilitates goal achievements;

- formation of trust with followers, by persistent implementation of actions aimed at achievement of the desired result;

- development of creative potential in the organization, based on self-respect and focusing on the strengths (a leader's positive example empowers employees, and also contributes to their commitment to learning and self-development).

Bennis and Nanus (1985) noted that leadership is the key element of the organization's success, that a modern transformational leader is a person who encourages people's activity, transforms followers into leaders, and leaders - into agents of change.

Development of the transformational leadership theory was contributed by James Kouzes and Barry Posner (1987, 2002), who analysed the answers of over 1300 top- and middle-managers as to their most successful leadership experiences. On the basis of content 
analysis of the obtained results, they formulated their model of transformational leadership consisting of the following five principles:

- "the personal/special way" modelling by the leader and the influence of the followers through communications and the personal behaviour model;

- inspiration of the followers by the leader for achieving the organization's vision development and visualization of positive results;

- the leader's readiness to challenge the situation, his desire for experimenting, finding new methods of improving organizational results;

- the leader's support of employees' initiative, their desire to demonstrate activity and creativeness, respect and trust for their points of view, ability to listen and apply other people's ideas;

- the leader's recognition of employees' work efficiency, ability of praising, evaluating their results, of demonstrating his appreciation.

The model of James Kouzes and Barry Posner $(1987,2002)$ is of advisory nature for people who strive to become an effective leader, it is comprehensible for any person and focuses rather not on a leader's personality, but on his behaviour.

Despite the popularity of transformational leadership theory and rather sheer magnitude, there is a certain criticism (Northouse, 2015). Thus, four factors of the transformational leadership (idealized influence, inspiring motivation, intellectual stimulation, individualized consideration) have many similarities, that is why it may be difficult to differentiate between them (Tracey \& Hinkin, 1998). Despite Bass's pointing out that the transformational leader's behaviour can be learned: "Transformational leadership can he learned and it can-and should - be the subject of management training and development. Research has shown that leaders at all levels can be trained to be charismatic...", there exists the opinion that inborn character traits are more important for a transformational leader, than behaviour which can be learned (Bryman, 1992). Besides, a transformational leader possesses the charismatic leader's traits, demonstrates his dominant role in relation to his followers, which can lead to authoritarianism and dictatorship (Burns, 1978). It is this transformational leader's propensity for domineering and, at times, "over-concern" about his followers that can lead to reduction in organizational results. Thus, Senge et al (1999) noted that the organization's focus on a "hero leader" can develop harmful consequences, as employees develop a focus on their leader's affection and winning his favour, instead of focusing on creating new products or processes. This, in turn, leads to a new crisis; even if in the beginning the desired results were achieved owing to the "hero leader". The adaptive leadership theory`s authors Heifetz \& Linsky (2009) emphasized the importance of the situation that a leader should not solve technical problems instead of his employees, but in case of complex adaptive challenges a leader should help to mobilize people to leave the comfort zone, to accept new challenges and ways to solve problems, to gain new knowledge and skills.

It should be mentioned that complex studies as to transformational and transactional leadership application in pharmacies and pharmaceutical organizations were practically not conducted. Thus, García-Morales et al (2008), conducting their research based on 164 firms, revealed the positive correlation between transformational leadership and organizational performance, as well as between transformational leadership and organizational innovation. Besides, the authors noted that this correlation grew considerably if the studied pharmaceutical companies possessed the corporate culture aimed at training and continuous organizational development. Aydogdu et al (2011), analysing the employees of pharmaceutical sphere, arrived at the conclusion that transformational leadership has a positive correlation with the corporate culture components facilitating employees' achievement of short-term and long-term objectives, their resistance reduction to organizational changes and the growth of intrinsic motivation. 
In Ukraine, the research on leadership, in particular, on transformational leadership theory in the pharmaceutical sphere is not conducted. Most often the attention is given to employees' motivation and to extrinsic motivators (Korniyenko et al., 2008; O. M. Tututchenko et al., 2010; Nemchenko et al., 2011; Teterich, 2015). In the studies, conducted among the employees of Ukrainian pharmacies and pharmaceutical enterprises (Aliekperova, 2018), it was found that a leader and his inspiring skills are an important motivation factor, as they contribute to internal desire of employees to achieve the organizational goals. According to the studies, the significance of this factor was secondary only to material motivation factors (promotion possibilities, cash bonuses, benefits package), and also to such non-material factors as the creation and support of friendly corporate climate and interesting and motivating work.

\section{Research methodology}

\subsection{Sampling justification}

To achieve the objectives of the study and definition of styles of transformational, transactional and laissez-faire leadership managers of pharmacies and pharmaceutical organizations in Ukraine the quantitative analysis was used - a questionnaire survey of employees and managers of organizations in this profile, the totality of which was considered as the target population (Bhattacherjee, 2012; Kumar, 2011; Walliman, 2016). As a sampling frame, we selected students of the pharmaceutical faculty of Bogomolets National Medical University of extramural form of education, which already have a degree of Junior Specialist. This degree is identical to the Bachelor's degree, and at the time of the survey students were employees and managers of pharmacies and pharmaceutical organizations in various regions of Ukraine: Kyiv, Zhytomyr, Chernihiv, Sumy, and other areas. Bhattacherjee (2012) noted that if target population is employees of organizations, then a more realistic sampling frame is employees of one or two local companies who are willing to participate in the study, since the coverage of all companies is unrealistic and extremely expensive. However, in this study, employees of one company are unlikely to be representative of the sampling frame, as the main share of target population is employees of pharmacies, with the staff of only a few people. Therefore, this study was attended by respondents who are employees and managers of pharmacies and pharmaceutical organizations from different regions of Ukraine, and their distance learning in Bogomolets National Medical University has made the process of collecting information accessible and convenient.

In this study, probability sampling techniques were used, which, as Walliman (2006) noted: "give the most reliable representation of the whole population", in particular, simple random sampling. This kind of sampling, according to Walliman (2006), "is used when population is uniform or has common characteristics in all cases". The number of respondents in the role of both employees and managers of pharmacies and pharmaceutical organizations in Ukraine is relatively low. However, as Kumar (2011) noted: "if a population is homogeneous (uniform or similar) with respect to the characteristics under study, a small sample can provide a reasonably good estimate".

In total, 127 employees' questionnaires and 16 managers' questionnaires were analysed and summarized (the survey was conducted during May-June 2017). The bulk of pharmacies and pharmaceutical organizations employees are women (83\%) up to 25 years of age $(77.2 \%)$, with pharmaceutical education $(93,7 \%)$, working in the sphere of pharmaceutical retail trade (pharmacies) $-83,5 \%$ and with work experience up to 5 years $(85,8 \%)$. Among the pharmacies and pharmaceutical organizations managers, the majority of respondents $(68,8 \%)$ are women; 43,8\% are between 26 and 34 years of age, with pharmaceutical education 
$(93,8 \%)$, having the term of service in management up to 5 years $(68,8 \%)$. For more detailed information about the respondents see Table 1.

Table 1. Respondents' characteristics

\begin{tabular}{|c|c|c|c|c|}
\hline \multirow[t]{2}{*}{ Evaluation criteria } & \multicolumn{2}{|c|}{ Number of respondents } & \multicolumn{2}{|c|}{ Percentage $(\%)$} \\
\hline & employees & managers & employees & managers \\
\hline $\begin{array}{l}\text { Gender: } \\
\text { male } \\
\text { female }\end{array}$ & $\begin{array}{c}22 \\
105\end{array}$ & $\begin{array}{c}5 \\
11\end{array}$ & $\begin{array}{l}17,3 \\
82,7\end{array}$ & $\begin{array}{l}31,3 \\
68,8\end{array}$ \\
\hline $\begin{array}{l}\text { Age: } \\
\text { up to } 25 \\
25-34 \\
35-44 \\
45-54 \\
\end{array}$ & $\begin{array}{c}98 \\
18 \\
10 \\
1 \\
\end{array}$ & $\begin{array}{l}4 \\
7 \\
3 \\
2\end{array}$ & $\begin{array}{c}77,2 \\
14,2 \\
7,9 \\
0,8\end{array}$ & $\begin{array}{c}25 \\
43,8 \\
18,8 \\
12,5\end{array}$ \\
\hline $\begin{array}{l}\text { Education: } \\
\text { pharmaceutical } \\
\text { medical } \\
\text { economic } \\
\text { pedagogical } \\
\text { chemical } \\
\text { biological } \\
\end{array}$ & $\begin{array}{c}119 \\
1 \\
2 \\
1 \\
1 \\
3 \\
\end{array}$ & $\begin{array}{c}15 \\
0 \\
0 \\
0 \\
1 \\
0\end{array}$ & $\begin{array}{c}93,7 \\
0,8 \\
1,6 \\
0,8 \\
0,8 \\
2,4 \\
\end{array}$ & $\begin{array}{c}93,8 \\
0 \\
0 \\
0 \\
6,3 \\
0 \\
\end{array}$ \\
\hline $\begin{array}{l}\text { Sphere of Pharmacy: } \\
\text { retail trade } \\
\text { wholesale trade } \\
\text { domestic pharmaceutical } \\
\text { manufacturer } \\
\text { distributor of a foreign } \\
\text { pharmaceutical company } \\
\text { other }\end{array}$ & $\begin{array}{c}106 \\
2 \\
9 \\
8 \\
2 \\
2\end{array}$ & $\begin{array}{l}6 \\
0 \\
5\end{array}$ & $\begin{array}{c}83,5 \\
1,6 \\
7,1 \\
6,3 \\
\\
1,6 \\
\end{array}$ & $\begin{array}{c}37,5 \\
0 \\
31,3 \\
18,8 \\
12,5 \\
\end{array}$ \\
\hline $\begin{array}{l}\text { Work experience: } \\
\text { up to } 5 \\
5-10 \\
10-15 \\
15-20 \\
25 \text { and above }\end{array}$ & $\begin{array}{c}109 \\
13 \\
3 \\
1 \\
1\end{array}$ & $\begin{array}{c}14 \\
4 \\
1\end{array}$ & $\begin{array}{c}85,8 \\
10,2 \\
2,4 \\
0,8 \\
0,8\end{array}$ & $\begin{array}{l}68,8 \\
25 \\
6,3\end{array}$ \\
\hline
\end{tabular}

\subsection{Data collection technique}

For measuring transformational, transactional and laissez-faire leadership, the Multifactor Leadership Questionnaire (MLQ) is most frequently applied, which was developed by Bass (1985) based on the survey of 70 senior executives in South Africa. Later the MLQ was amended and reviewed, its various versions were created, and its high validity was confirmed by a number of studies (Avolio et al., 1999, Tejeda, 2001).

In this study MLQ-6S was applied, which was developed by Bass and Avolio (1992), however, it was amended by another three questions (the total number of questions was 24 instead of 21), which allowed the management-by-exception divide into active and passive, as later Bass and Avolio (1994) noted their different impact on employees' effectiveness. For each factor (idealized influence, inspiring motivation, intellectual stimulation, individualized consideration, contingent reward, MBE-active, MBE-passive, laissez-faire leadership) three questions characterizing a leader's behaviour were offered. Employees evaluated their managers, and managers of Ukrainian pharmacies and pharmaceutical organizations evaluated 
themselves according to the following scale: 0 - not at all; 1 - once in a while; 2 - sometimes; 3 - fairly often; 4 - frequently, if not always. Grade range: high $(9-12)$, medium $(5-8)$, low $(0-40)$.

\section{Research results}

Perceptual measures by the employees of Ukrainian pharmacies and pharmaceutical organizations of their managers' behaviour, as well as perceptual measures of the managers of Ukrainian pharmacies and pharmaceutical organizations themselves of their own leadership behaviour according to the transformational and transactional leadership theory, are represented in Table 2 and Table 3.

Table 2. Employees' perception of their managers' leadership behaviour in Ukrainian pharmacies and pharmaceutical organizations

\begin{tabular}{lccccc}
\hline Leadership factor & \multicolumn{5}{c}{ Percentage (\%) } \\
\cline { 2 - 6 } & Not at all & $\begin{array}{c}\text { Once in } \\
\text { a while }\end{array}$ & $\begin{array}{c}\text { Some- } \\
\text { times }\end{array}$ & $\begin{array}{c}\text { Fairly } \\
\text { often }\end{array}$ & $\begin{array}{c}\text { Frequently, if } \\
\text { not always }\end{array}$ \\
\hline Idealized influence & 7,06 & 10,26 & 18,9 & 30,96 & 32,8 \\
\hline Inspirational motivation & 9,43 & 9,16 & 14,96 & 30,43 & 35,96 \\
\hline Intellectual stimulation & 4,46 & 10,23 & 23,63 & 34,9 & 26,7 \\
\hline Individualized consideration & 7,6 & 11,26 & 19,66 & 32,26 & 29,13 \\
\hline Contingent reward & 4,73 & 12,33 & 19,13 & 30,16 & 33,6 \\
\hline MBE-active & 4,2 & 9,7 & 17,03 & 34,6 & 34,4 \\
\hline MBE-passive & 31,5 & 23,9 & 21 & 17,06 & 6,56 \\
\hline Laissez-faire & 44,6 & 29,13 & 16,3 & 6,3 & 3,66 \\
\hline
\end{tabular}

Table 3. Managers' perception of their own leadership behaviour in Ukrainian pharmacies and pharmaceutical organizations

\begin{tabular}{lccccc}
\hline Leadership factor & \multicolumn{5}{c}{ Percentage (\%) } \\
\cline { 2 - 6 } & Not at all & $\begin{array}{c}\text { Once in } \\
\text { a while }\end{array}$ & $\begin{array}{c}\text { Some- } \\
\text { times }\end{array}$ & $\begin{array}{c}\text { Fairly } \\
\text { often }\end{array}$ & $\begin{array}{c}\text { Frequently, if } \\
\text { not always }\end{array}$ \\
\hline Idealized influence & 0 & 0 & 12,5 & 35,4 & 52,1 \\
\hline Inspirational motivation & 2,1 & 2,1 & 10,43 & 25,03 & 60,43 \\
\hline Intellectual stimulation & 0 & 0 & 4,16 & 41,7 & 54,2 \\
\hline Individualized consideration & 4,2 & 0 & 8,36 & 33,36 & 54,16 \\
\hline Contingent reward & 0 & 0 & 2,1 & 16,7 & 81,26 \\
\hline MBE-active & 0 & 4,16 & 10,46 & 43,76 & 41,7 \\
\hline MBE-passive & 37,53 & 27,13 & 22,93 & 8,36 & 4,2 \\
\hline Laissez-faire & 56,3 & 37,53 & 6,26 & 0 & 0 \\
\hline
\end{tabular}

According to the results obtained, employees of pharmacies and pharmaceutical organizations evaluate the transformational factors in their managers' behaviour rather as 'fairly often' and 'frequently, if not always': the average values of these estimates are $63,28 \%$. Most often, according to employees, their managers demonstrate 'inspirational motivation' - $66.39 \%$, the second place is taken by the evaluation 'idealized influence' $(63,76 \%)$. Alongside, 'inspirational motivation' has the highest score in evaluating 'not at all' $-9,43 \%$. It should be noted that Bass and Avolio (1994) considered inspiring factors and 
idealized influence to be of the most effective impact among all the four transformational leadership factors.

Among all the eight factors, the most frequently used by the managers is, according to employees of Ukrainian pharmacies and pharmaceutical organizations ('fairly often' and 'frequently, if not always'), MBE-active (69\%). This factor has neither a positive, nor a negative influence on the employees' work efficiency, and in consequence, on the organizational efficiency (Bass and Avolio, 1994). The lowest score in the estimation of 'fairly often' and 'frequently, if not always' was marked for the following factors: passive management-by-exception and laissez-faire; 23,62\% and 9,96\% accordingly. Both of these factors characterize ineffective leadership behaviour which demotivates the employees and decreases their activity effectiveness and resulting quality (Bass and Avolio, 1994).

The managers evaluated their transformational and transactional leadership much higher than the employees of Ukrainian pharmacies and pharmaceutical organizations did. The average value of the four transformational factors in estimation of 'fairly often' and 'frequently, if not always' is $89 \%$. At that, the managers' perception of all four transformational leadership factors mainly corresponds to the evaluation of 'frequently, if not always': the average score is $55,22 \%$, while with the employees this indicator is $31,14 \%$.

Most frequently, according to the managers of Ukrainian pharmacies and pharmaceutical organizations, they apply such a transactional leadership factor as a 'contingent reward': $81,26 \%$ of managers noted that they used it frequently, if not always, while only $33,6 \%$ of employees evaluated their managers' application of this factor with 'frequently, if not always'.

Most seldom, the managers of pharmacies and pharmaceutical organizations apply such transactional leadership factor as MBE-passive: according to the estimates of 'fairly often' and 'frequently, if not always' it was marked by only $6,28 \%$ respondents. $6,26 \%$ managers marked their occasional use of laissez-faire leadership.

Range scores of transformational, transactional and laissez-faire leadership factors are represented in Table 4.

Table 4. Managers' and employees' range scores of leadership factors in Ukrainian pharmacies and pharmaceutical organizations

\begin{tabular}{lllc}
\hline Leadership factor & High scores (9-12) & Middle scores (5-8) & Low scores (0-4) \\
\hline Idealized influence & managers $-10,18$ & employees $-8,16$ & - \\
\hline Inspirational motivation & managers $-10,93$ & employees $-8,22$ & - \\
\hline Intellectual stimulation & managers $-10,5$ & employees $-8,07$ & - \\
\hline $\begin{array}{l}\text { Individualized } \\
\text { consideration }\end{array}$ & managers -10 & employees $-7,92$ & - \\
\hline Contingent reward & managers $-11,37$ & employees $-8,26$ & - \\
\hline MBE-active & managers $-9,68$ & employees $-8,56$ & managers $-3,43$ \\
\hline MBE-passive & - & - & $\begin{array}{l}\text { managers }-4,37 \\
\text { employees }-2,85\end{array}$ \\
\hline Laissez-faire & - & - &
\end{tabular}

It is necessary to specify that notwithstanding the employees' evaluation of all transformational and transactional leadership factors (except MBE-passive) with the medium score, and the managers' evaluation of the same with the high score, the tendency in their evaluations is very similar. The correlation coefficient among all the factors of transformational, transactional and laissez-faire leadership for the employees and the 
managers constitutes 0,81 , and this testifies to rather a strong link between the employees' and the managers' opinions of pharmacies and pharmaceutical organizations of Ukraine.

It is worth noting that such a transactional leadership factor as MBE-passive is quite similar to laissez-faire leadership in its impact: it has a negative effect on the motivation of employees, their job satisfaction, and the effectiveness of the leader (Judge et al., 2004). However, Avolio (1999) and Bass (1998) noted that laissez-faire leadership should be treated separately from transactional leadership factors because it represents the absence of leadership. In this regard, MBE-passive is considered in the context of transactional leadership, despite its fundamental differences with other transactional factors, especially with content reward. MBE-passive has low scores on the part of both employees and managers of pharmacies and pharmaceutical organizations in Ukraine, in contrast to content reward and MBE-active, so the average value of transactional leadership factors was lower than the same indicator for transformational leadership. According to the results of the study, the employees of pharmacies and pharmaceutical organizations evaluated the use of transformational and transactional leadership by their management at middle scores, while managers evaluated their transformational leadership style at high score (Fig. 1).

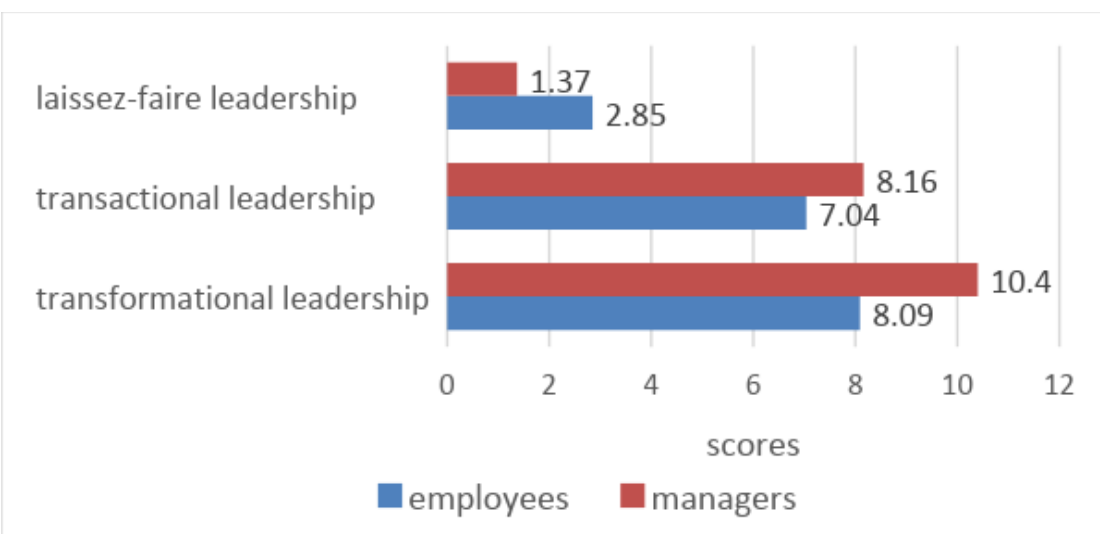

Figure 1. Distribution of transformational, transactional and laissez-faire leadership in pharmacies and pharmaceutical organizations in Ukraine based on the survey results of managers and employees.

The transformational leadership factors (idealized influence, inspiring motivation, intellectual stimulation, individualized consideration) have a high enough consistency degree among them, especially as concerns the evaluations of employees of Ukrainian pharmacies and pharmaceutical organizations: the variation coefficient for the employees and managers constituted $1,6 \%$ and 3,84\% accordingly. The transactional leadership factors have a weak correlation because of low evaluations of the MBE-passive factor compared to the medium (by the employees) and the high (by the managers) evaluations of other transactional leadership factors: contingent reward and MBE-active (see Table 5). 
Table 5. The Mean, St. Deviation, Coef. of Variation scores of employees and managers of Ukrainian pharmacies and pharmaceutical organizations in relation to the transformational and transactional leadership factors

\begin{tabular}{lcccccc}
\hline \multicolumn{1}{c}{ Variable } & \multicolumn{3}{c}{ Employees } & \multicolumn{3}{c}{ Managers } \\
\cline { 2 - 7 } & Mean & $\begin{array}{c}\text { St. } \\
\text { Deviation }\end{array}$ & $\begin{array}{c}\text { Coef. of } \\
\text { Variation, } \\
\%\end{array}$ & Mean & $\begin{array}{c}\text { St. } \\
\text { Deviation }\end{array}$ & $\begin{array}{c}\text { Coef. of } \\
\text { Variation, } \\
\%\end{array}$ \\
\hline $\begin{array}{l}\text { Transformational } \\
\text { factors }\end{array}$ & 8,09 & 0,13 & 1,6 & 10,40 & 0,4 & 3,84 \\
\hline Transactional factors & 7,04 & 2,37 & 33.6 & 8,16 & 4,18 & 51,22 \\
\hline
\end{tabular}

It is worth noting that the four transformational leadership factors (idealized influence, inspiring motivation, intellectual stimulation, individualized consideration) and two transactional leadership factors (contingent reward and MBE-active) are coordinated. The coefficient of variation for these six factors is $2,56 \%$ for the employees and $5,93 \%$ for the managers of Ukrainian pharmacies and pharmaceutical organizations. Judge and Piccolo (2004) noted as the result of conducting a complex meta-analysis that "transformational and transactional leadership are so highly related that it makes it difficult to separate their unique effects".

With consideration of the results obtained, it is possible to form the following practical recommendations for the leaders of Ukrainian pharmacies and pharmaceutical organizations:

1. Pay more attention to the transformational leadership factors (idealized influence, inspirational motivation, intellectual stimulation, individualized consideration), without which, according to B. Bass's transformational theory, the innovative sustainable organizational development is impossible. According to the study results, about $17 \%$ of employees of pharmacies and pharmaceutical organizations confirmed that the transformational leadership factors are practically not implemented in their professional activity.

2. In practice, idealized influence is realized through formulation of a clear and understandable vision of the development of the organization by the leader, by means of setting ambitious but realistic goals, demonstration of the leader's own positive example and illustrative behaviour for the employees; this, in turn, influences the formation of organizational culture, which is favourable for sustainable development.

3. Inspirational motivation can be realized through effective communicational interaction of the organization's leader and his employees, through application of emotional and inspirational influence techniques, of various trappings and symbols and elements of team-building by the managers in pharmacies and pharmaceutical organizations.

4. The individualized consideration factor implies an attentive leader's attitude to each member of organization, the formation of positive and friendly team climate, the ability to recognize and satisfy people's needs. It is this factor that has the lowest range score among all the transformational leadership factors, according to employees, as well as managers of pharmacies and pharmaceutical organizations.

5. While realizing intellectual stimulation in practice, the organization's leader pays attention to his employees' intellectual creative development, to the creation of conditions which allow focusing on people's strengths and to fully unlock their professional potential, which doubtlessly will be the key to competitive advantages of pharmacies and pharmaceutical organizations under conditions of rapidly changing external environment factors.

6. The transformational leadership enhances the transactional leadership effect and allows getting "performance beyond expectation" (Bass andAvolio, 1994), as it 
stimulates the internal motivation factors to a greater degree, while the transactional leadership stimulates the external ones. External motivation factors, tangible ones as a rule, are basic ones for the business environment, however, they are not sufficient enough for effective and long-term organization's development, which is confirmed by various motivation theories (Herzberg, 2003, Ryan and Deci, 2000).

7. The most efficient transactional factor that has a positive influence on work effectiveness of organization's employees is a contingent reward, which implies a well-defined goal- and task setting, and also employees' motivation by remuneration when a planned result is achieved. This transactional leadership style, in the opinion of managers in Ukrainian pharmacies and pharmaceutical organizations, is the one to be used most frequently. However, it provides orientation rather on external motivation, that on internal one, which is not sufficient enough while ambitious and complicated goals are to be achieved; sometimes it can lead to negative consequences. For instance, the stimulation of pharmacists with a bonus aimed at sales growth can lead to a desirable short-term result; however, persistent "hard-selling" of some drugs and health care products can be contrary to the pharmaceutical care and ethics principles, and it effects negatively both a pharmacist's self-assessment as a healthcare system specialist, and a pharmacy's image in the minds of customers.

8. The MBE-active transactional factor is neither a motivating, nor an inspiring one for employees, however, it does not have any demotivation impact upon them (Bass and Avolio, 1994); while Northouse (2015) argued that "both the active and passive management use more negative reinforcement patterns than positive...". In employees' view, it is the MBE-active that is the most frequently used leadership behaviour: $34,4 \%$ of employees marked it to be used by their managers 'frequently, if not always' and 34,6\% employees marked it as 'fairly often' used.

9. The MBE-passive means that managers get involved into the process only on its completion and only in the event that some problems occur: this leadership factor has a negative influence on employees and on obtaining a desirable result. It is worth noting that $17 \%$ of employees marked that their managers applied this transitional leadership factor rather often.

The most negative leadership style is the laissez-faire leadership, which implies the lack of a manager's desire and readiness to take responsibility, to take managerial decisions, to interact with employees effectively, to organize feedback; and this produces an utterly negative influence of the employees' work results, the inner climate in the team and results in poor financial indicators. About $16 \%$ of pharmacies and pharmaceutical organizations' employees confirmed that their managers sometimes use such leadership behaviour.

\section{Limitations}

The participants of the study were mainly students (junior specialists) of Bogomolets National Medical University. They work in pharmacies and pharmaceutical organizations and, at the same time, take distance courses for obtaining the Specialist's degree in pharmacy. Most of them work in pharmacies, and their average age is about 25, and work experience is up to 5 years; these factors can certainly have an impact on their perception of their managers' leadership style. Thus, a small work experience and a relatively young age can testify to the fact that the respondents had no possibility of comparing different leadership styles, they probably lacked experience for the adequate and comprehensive evaluation for their managers' behaviours.

In addition, the study involved employees and managers of pharmacies and pharmaceutical organizations not from all regions of Ukraine. However, respondents' 
answers, regardless of their place of residence, had a high degree of consistency, which minimizes the criticality of this factor.

Notwithstanding the fact that the MLQ validity was confirmed in various studies, nevertheless in the countries of Eastern Europe and in Ukraine in particular, complex studies with the MLQ application were not conducted. The number of respondents, especially the number of managers of pharmacies and pharmaceutical organizations having participated in this research, is not big, and this influences the sampling error index. Nevertheless, the selection structure, which is determined in accordance with the study's objective and tasks, testifies to the reliability of the results obtained.

\section{Conclusion}

According to the results obtained, the transformational leadership factors (idealized influence, inspiring motivation, intellectual stimulation, individualized consideration), the transactional leadership factors (contingent reward, MBE-active, MBE-passive) and also the laissez-faire leadership have relatively similar estimates both on the part of the employees and managers in Ukrainian pharmacies and pharmaceutical organizations; the correlation coefficient is 0,81 .

At that, the employees gave the medium score (the arithmetic mean is 8,9) to their managers' application of all transformational leadership factors and two transactional leadership factors, while the managers themselves gave themselves a high score (the arithmetic mean is 10,44). It's most likely that the evaluation discrepancy testifies to the greater managers' subjectivity while evaluating their own leadership behaviour. Both the employees, and managers of Ukrainian pharmacies and pharmaceutical organizations evaluated the factors of MBE-passive and laissez-faire leadership with low scores: the arithmetic mean of these two indicators for the employees was 3,57, and for the managers 2,4. It is these two indicators (Bass \& Avolio, 1994) that characterize ineffective leadership, which exercises the negative influence both on the employees' satisfaction, and on their work indices.

The highest evaluation was given by the employees of pharmacies and pharmaceutical organizations to the MBE-active factor of the transactional leadership, which, as a rule, has neither a positive, nor a negative effect on the employees' satisfaction. At the same time, the managers gave the highest score $(11,37)$ to the transactional leadership factor of contingent reward. This factor is "reasonably effective", as it implies setting well-defined goals and the formation of a remuneration system aimed at goal achievement (Avolio, 1999). Besides, Judge and Piccolo (2004) revealed that the contingent reward's validity in the business sphere is far stronger than in other spheres.

In general, the two transactional leadership factors, contingent reward and MBEactive, were evaluated both by the employees, and the managers of Ukrainian pharmacies and pharmaceutical organizations with higher scores than other factors, which also confirms the augmentable effect of the transformational leadership on the basis of transactional leadership. As Bass (1998) argued: "transformational leadership styles build on the transactional base in contributing to the extra effort and performance of followers". He also focused on the fact that an effective leader is both a transactional leader and a transformational one. 


\section{References}

Aliekperova, N. (2018). Motivating factors effecting work efficiency of employees in Ukrainian pharmaceutical sector. Economics and Sociology, 11(1), 61- 74.

Avolio, B. J. (1999). Full leadership development. Thousand Oaks, CA: Sage.

Avolio, B. J., Bass, B. M., \& Jung, D. I. (1999). Re-examining the components of transformational and transactional leadership using the Multifactor Leadership Questionnaire. Journal of Occupational and Organizational Psychology, 72, 441-462.

Aydogdu, S., Asikgil, B. (2011). The Effect of Transformational Leadership Behavior on Organizational Culture: An Application in Pharmaceutical Industry. International Review of Management and Marketing, 1(4), 65-73.

Bass, B. M., \& Avolio, B. J. (1994). Improving organizational effectiveness through transformational leadership. Thousand Oaks, CA: Sage.

Bass, B. M. (1985). Leadership and performance beyond expectations. New York: Free Press.

Bass, B. M. (1990) From transactional to transformational leadership: Learning to share the vision. Organizational Dynamics, 18, 19-31.

Bennis, W.G., \& Nanus, B. (1985). Leaders: The strategy for taking charge. New York: Harper\&Row.

Bhattacherjee, A. (2012). Social Science Research: Principles, Methods, and Practices. Textbooks Collection. 3. Retrieved from http://scholarcommons.usf.edu/oa_textbooks/3

Burns, J. M. (1978). Leadership. New York: Harper\&Row.

EvaluatePharma World Preview 2017. (2017). Retrieved July 04, 2018, from http://www.evaluate.com/PharmaWorldPreview2017.

García-Morales, V. J., Matías-Reche, F., \& Hurtado-Torres, N. (2008). Influence of transformational leadership on organizational innovation and performance depending on the level of organizational learning in the pharmaceutical sector. Journal of Organizational Change Management, 21(2), 188-212.

Gryazeva-Dobshinskaya, V. G., \& Dmitrieva, Yu. A. (2014). Structure leadership of managers: Results of empirical research (Struktura liderstva menedgerov: resultati empiricheskogo issledovaniya). Bulletin of the South Ural State University, 7(4), 5-12 (rus).

Heifetz, R., Grashow, A., \& Linsky, M. (2009). The practice of adaptive leadership: Tools and tactics for changing your organization and the world. Boston, Mass.: Harvard Business Press.

Herzberg, F. (2003). One more time: How do you motivate employees. Harvard Business Review, 81, 86-96.

House, R. J. (1976). A 1976 theory of charismatic leadership. In J. G. Hunt \& L. L. Larson (Eds.), Leadership: The cutting edge (pp. 189-207). Carbondale, IL: South Illinois University Press.

Judge, T.A., \& Piccolo, R.F. (2004). Transformational and transactional leadership: A metaanalytic test of their relative validity. Journal of Applied Psychology, 89(5), 755-768.

Jung, D.I., Chow, C., \& Wu, A. (2003). The role of transformational leadership in enhancing organizational innovation: Hypotheses and some preliminary findings. The Leadership Quarterly, 14, 525 - 544.

Korniyenko, O. M., Horodetska, I. Ya., Levytska, O. R., \& Yunikov, R. S. (2008). Aspects of provisors' professional motivation and prestige factors of higher educational establishments (Aspekti professiynoi motivatzii provisoriv chinniki prestigu visshih uchebnih zakladiv). Pharmaceutical review, 3, 95-98. (ukr).

Kouzes, J.M., \& Posner, B.C. (1987). The leadership challenge: How to get extraordinary things done in organizations. San Francisco: Jossey-Bass. 
Kouzes, J.M., \& Posner, B.C. (2002). The leadership challenge (3-th ed.) San Francisco: Jossey-Bass.

Kumar, R. (2011). Research Methodology: A Step-by-Step Guide for Beginners. 3rd Edition. Sage, New Delhi.

Lowe, K. B., Kroeck, K. G., \& Sivasubramaniam, N. (1996). Effectiveness correlates of transformation and transactional leadership: A metaanalytic review of the MLQ literature. Leadership Quarterly, 7, 385-425.

Nemanich, L.A., \& Keller, R.T. (2007). Transformational leadership in an acquisition: A field study of employees. Leadership Quarterly, 18, 49-68.

Nemchenko, A. S., Yurchenko, G. M, \& Jirova, I. V. (2011). The analysis of motivational principles of personnel management of the pharmaceutical organization (Analiz motivaziynich prinzipiv upravlinya personalom pharmacevticheskoy organizacii). Management, Economics and Quality Assurance in Pharmacy, 1, 18-23 (ukr).

Northouse, P.G. (2015). Leadership: Theory and practice (7-th ed.). Thousand Oaks, CA: SAGE.

Paulsen, N., Callan, V.J., Ayoko, O., \& Saunders, D. (2013). Transformational leadership and innovation in an R\&D organization experiencing major change. Journal of Organizational Change Management, 26(3), 595-610.

Rabia, I., Afsheen, F., \& Abaid, R. (2009). Transformational leadership and organizational innovation: Moderated by organizational size. African Journal of Business Management, 3(11), 678-684.

Rowold, J., \& Heinitz, K. (2007). Transformational and charismatic leadership: Assessing the convergent, divergent and criterion validity of the MLQ and the CKS. Leadership Quarterly, 18, 121-133.

Ryan, R.M., \& Deci, E.L. (2000). Self-determination theory and the facilitation of intrinsic motivation, social development, and well-being. American Psychologist, 55(1), 68-78.

Sagnak, M., Kuruoz, M., Polat, B, \& Soylu, A. (2015). Transformational leadership and innovative climate: An examination of the mediating effect of psychological empowerment. Eurasian Journal of Educational Research, 60, 149-162.

Senge, P., Kleiner, A., Roberts, C., Roth, G., \& Ross, R. (1999). The dance of change: The Challenges of Sustaining the Learning Organization. Doubleday, New York.

Teterich, N.V. (2015). Scientific ground of basic going near motivation of pharmaceutical workers (Naukove obgruntuvannya osnovnih pidhodiv do motivatzii pharmazevtichnih prazivnikiv). Pharmaceutical review, 3, 44-47 (ukr).

Tracey, J. B., \& Hinkin, T. R. (1998). Transformational leadership or effective managerial practices? Group \& Organization Management, 23, 220-236.

Tututchenko, O.V., Pestun, I.V., \& Mnushko, Z.N. (2010). Pharmacists' motivation as the constituent of strategic plan realization of a pharmacy enterprise (Motyvatziya provisiriv yak skladova realizacii strategichnogo planu aptechnogo pidpriyemstva). Vestnik of Pharmacy, 1, 47-50 (ukr).

Xenikou, A. (2017). Transformational Leadership, Transactional Contingent Reward, and Organizational Identification: The Mediating Effect of Perceived Innovation and Goal Culture Orientations. Frontiers of Psychology, 8, 1754.

Walliman, N. (2006). Social research methods. London: SAGE publications.

Zwingmann, I., Wegge, J., Wolf, S., Rudolf, M., Schmidt, M., \& Richter, P. (2014). Is transformational leadership healthy for employees? A multilevel analysis in 16 nations. German Journal of Research in Human Resource Management, 28(1-2), 24-51. 